\title{
Effect of Brand Equity on the Performance of Distributors in Flour Mills of Nigeria PLC
}

\author{
Solomon Abba Boman ${ }^{1, ~ *, ~ T i j j a n i ~ B a s h i r ~ M u s a ~}{ }^{2}$, Agbo Onu ${ }^{3}$, Ismail Tijjani Idris ${ }^{2}$ \\ ${ }^{1}$ Department of Management Studies, Ahmadu Bello University, Zaria, Nigeria \\ ${ }^{2}$ Department of Finance, Ahmadu Bello University, Zaria, Nigeria \\ ${ }^{3}$ Department of Marketing, Ahmadu Bello University, Zaria, Nigeria
}

Email address:

soloboman@yahoo.com (S. A. Boman)

*Corresponding author

\section{To cite this article:}

Solomon Abba Boman, Tijjani Bashir Musa, Agbo Onu, Ismail Tijjani Idris. Effect of Brand Equity on the Performance of Distributors in Flour Mills of Nigeria PLC. International Journal of Business and Economics Research. Vol. 8, No. 3, 2019, pp. 108-117. doi: $10.11648 /$ j.ijber.20190803.14

Received: April 16, 2019; Accepted: June 3, 2019; Published: June 17, 2019

\begin{abstract}
The rapid growth of fast moving consumer goods market in Nigeria has brought competition, making firms to focus on the performance of distributors or loose to competitors. In order for fast moving consumer goods companies such as Flour Mills of Nigeria PLC to grow and ensure profitability, product distribution become critical. The objective of this study is to assess the effect of brand equity on the performance of distributors in Flour Mills of Nigeria PLC focusing on the north central region of Nigeria. The study is a survey research, data were collected using self-administered questionnaire, and the formulated hypotheses tested using multiple regressions with the help of SPSS IBM 23. The findings of the study revealed that the level of performance of distributors in Flour Mills of Nigeria PLC is greatly influenced by factors such as Product's brand acceptance and product perceive quality which increases market share of the company. The study concluded that the positive effect of brand equity on performance of distributors in Flour Mills of Nigeria PLC is very high. And therefore recommended that creating intensive awareness about the Company activities will improve the Performance of distributors, requisite quality measures such as date of manufacture, expiry date, basic instruction on how to use the product and the production ingredients or contents that make up the product will create confidence in the mind of customers. Also, measures such as quantity and quality increase, effective distribution channels and affordability will increase customer's satisfaction.
\end{abstract}

Keywords: Brand Equity, Performance, Distributors, Flour Mill of Nigeria

\section{Introduction}

The fast-Moving Consumer Goods sector such as Flour Mills of Nigeria PLC is a key contributor of the Nigeria economy. This sector provides products that are daily consumed by each and every strata of the society irrespective of social class, income group, age group etc. As manufacturing and distribution of fast moving consumer goods in Nigeria continue to expand, driven by the Government's efforts to encourage consumption of made in Nigeria goods, promote local and foreign investment in the sector, and discourage imports, the need for a company like Flour Mills of Nigeria PLC to focus on the performance of distributors of her products cannot be overemphasized.
A distributor is a middleman that helps a company on their international or domestic markets, they usually has an exclusive right to sale on a specific market while working closely with the manufacturer continuously over a long period in which the manufacturer still maintaining control over prices, marketing, service and other functions. One benefit of the collaboration is that the manufacturer doesn't have any fixed cost to be responsible of, which they would have if they entered the market on their own. Hence the need to emphasize on the performance of distributors.

The concept of performance is multidimensional involving elements such as economic performance (sales, productivity, profit), social performance (employee and customer satisfaction), legal performance (obeying of laws and law 
like recommendations), or social performance (adoption of conduct norms based on ethical considerations)[1] Performance also comprises of financial and non-financial performance. It provides the information necessary for decision makers to plan, control and direct the activities of an organization.

A more robust approaches to performance which this study focused on include the intangible dimensions, such as public image perception, quality perception, customer satisfaction, employee satisfaction, brand positioning strategies of a firm, economic value of a product, skills levels, innovations in products and services investments into training and new value streams among others, as opined by Aaker [2]. When a customer is satisfied with a particular product brand, it may lead to brand loyalty, which eventually results to brand equity.

Brand equity is the market power, economic growth, and financial value inherent in the goodwill and reputation that a well-established brand name has built up over the period of its existence [3]. Brand equity is foremost among the most valuable but intangible marketing assets a firm can have and these constructs have continued to be an important subject matter in marketing [4].

With the increase of various brands in the fast moving consumer goods industry such as Flour Mills of Nigeria PLC, it is important that the perception that people have of the products shall be high. Brand equity help customers in interpreting and processing information, create confidence in purchasing decisions and also enhance customers' satisfaction. Brand equity help companies to increase the efficiency and effectiveness of their marketing programs in other to enjoy higher profit margins. Aaker [2], posited that brand equity can be based on five dimensions: perceived quality, brand awareness, brand associations, brand loyalty, in addition to other proprietary brand assets (patents, trademarks, channels relationships and so on).

The study of brand equity can be approached from two perspectives, from the perspective of the consumer and from the perspective of the firm [2]. However, this study considers brand equity from the perspective of the firm with emphasis on the performance of distributors in Flour Mill of Nigeria plc. This involves the use of observed market data to assess the value that the brand accrued to the firm. It is in the light of this that this study assesses the effect of brand equity on performance of distributors in Flour Mills of Nigeria PLC.

\subsection{Statement of the Problem}

Rapid growth of fast moving consumer goods market in Nigeria has brought competition, making firms to focus on the performance of distributors or loose to competitors. In order for fast moving consumer goods companies such as Flour Mills of Nigeria PLC to grow and at the same time not risking huge amount of time and money setting up sales offices in other to outsmart competition, distributors become more interesting. A conflict of interest arises when the distributors both want to promote other competitors' brand and simultaneously sale the products from the manufacturer.
The managerial implications is how to manage the relationship with the distributors and how to educate them on how to handle the manufacturers brand in order not to make it contradictory towards competitors brand values.

The major problem marketers of fast moving consumer goods such as Flour Mills of Nigeria PLC has contended with is how to build up brand equity and ensure that customers are satisfied and that this satisfaction result to continuous purchase and improve the performance of distributors in Flour Mills of Nigeria PLC. Thus, to consider whether the type, strength and magnitude of possible effect between components of brand equity and distributors performance indicators such as public image perception, quality perception, customer satisfaction, employee satisfaction, brand positioning strategies, economic value of a product, skills levels, innovations in products and new value streams can lead to meaningful managerial implications. Since, there is a noticed gap and dearth of studies that focused on the effect of brand equity on the performance of distributors of Nigerian food and beverages companies such as Flour Mill of Nigeria plc, this study fill that gap.

\subsection{Research Questions}

This study addresses the following questions:

a. In what ways does perceived product quality affect performance of distributors in Flour Mills of Nigeria PLC?

b. To what extent does brand awareness affect performance of distributors in Flour Mills of Nigeria PLC?

c. To what extend does brand association affect performance of distributors in Flour Mills of Nigeria PLC?

d. In what ways does brand loyalty affect performance of distributors in Flour Mills of Nigeria PLC?

\subsection{Objectives of the Study}

The main objective of this study is to assess the effect of brand equity on the performance of distributors in Flour Mills of Nigeria PLC. The study seeks to:

a. a. Determine the effect of perceive product quality on performance of distributors in Flour Mills of Nigeria PLC.

b. Find out the effect of brand awareness on performance of distributors in Flour Mills of Nigeria PLC.

c. Ascertain the effect of brand association on performance of distributors in Flour Mills of Nigeria PLC.

d. Establish the effect of brand loyalty on performance of distributors in Flour Mills of Nigeria PLC.

\subsection{Research Hypotheses}

The following research hypotheses have been formulated for validation in line with the research questions:

$\mathrm{H} 0_{1}$. There is no significant effect of perceived product quality on the performance of distributors in Flour Mills of 
Nigeria PLC.

$\mathrm{HO}_{2}$. There is no significant effect of Brand awareness on performance of distributors in Flour Mills of Nigeria PLC.

$\mathrm{HO}_{3}$. There is no significant effect of brand association on performance of distributors in Flour Mills of Nigeria PLC.

$\mathrm{HO}_{4}$. There is no significant effect of Brand loyalty on performance of distributors in Flour Mills of Nigeria PLC.

\section{Literature Review and Theoretical Framework}

\subsection{Concept of Brand Equity}

Brand Equity is an intangible asset that depends on associations made by the consumer. Its value is based on how much a customer is aware of a brand and is built-up in a brand over the period of its existence. The brand can add significant value when it is well recognized and has positive associations in the mind of the consumer. This concept namely, the positive associations of the brand in the mind of the consumer, is what we refer to as Brand equity [5]. There are mainly two perspectives in interpreting the concept of brand equity: financial-base perspective and consumer- based perspectives.

Kotler and Keller [3] define brand equity as the added value endowed to product and services. This value may be reflected in how consumers think, feel, and act with respect to the brand, as well as the prices, market share, and profitability that the brand commands for the firm. For our purpose, brand equity is an added value made over time as a result of goodwill and general acceptance of Flour Mills of Nigeria products in Nigerian food and beverages market.

\subsection{Concept of Performance}

Currently there are a variety of definitions attributed to the concept of performance due to its subjective nature. Michel [6] define performance as future-oriented, designed to reflect particularities of each organization/individual and is based on a causal model linking components and products. According to Wholey [7], performance may include components, products, consequences, impact and can also be linked to economy, efficiency, effectiveness, cost effectiveness or equity.

According to Kane [8], performance is defined at the level of each individual within the organization or at organization level. It is perceived as an understanding of the achieved results. Brumbach [9], define Performance to mean both behaviours and results. Behaviours are emanating from the performer and turn the performance of an abstract concept into a concrete action. Not being just tools of obtaining some results, behaviours are by themselves outcomes - the product of the physical and cerebral exercise submitted for the execution of tasks and can be judged apart from results". Thus, the author defines performance closely related to behaviour and outcomes. The above definition of performance can be translated into another equivalent definition to mean that Performance in the enterprise represents all that contributes to the achievement of strategic objectives. Performance is not a mere finding of an outcome, but rather it is the result of a comparison between the outcome and the objective.

\subsection{Dealer-Based Brand Equity}

Keller [10] proposed that customers, includes individuals as well as organizations, for example business organization such as the dealers. Based on Omar [11], a dealer is someone who aids, supports, and serves the manufacturer (or firm). According to Rosenbloom [12], a dealer can be referred as a retail trade organization that engaged primarily in selling merchandise for personal or household consumption and rendering services incidental to the sale of goods. Due to dealer's response tapping the scope of brand equity assets, hence, by following Aaker [2], the dealer-based brand equity in this study is defined as, "a set of brand assets and liabilities linked to a brand carried by them that add to or subtract from the value provided by a product or service to a firm and/or to themselves as a firm's customers".

Dealers are also involved with marketing research activities organized by the firms and reporting the firm market performance, analyzed for the firm competitor brand information, promoting the firm brand informing any customer complaints or recommendations on behalf of firm customer; and any other task related for customer's motivation, comfortable and satisfaction. Consistent with Baldauf [13], this means that, the dealers are the entity that's responsible for marketing the firm brand acts as the interface between consumers and firm, possesses knowledge regarding the perceptions and preferences of its customers; and is aware of the market performance and relative profitability of the firm brand that it distributed.

\subsection{Measurement of Brand Equity}

One of the main concerns for marketing managers, beside building strong brands, is measuring the health of their brand. This is done through "brand equity". Brand equity is one of the most valuable assets an enterprise has, therefore, there is a need to develop measures of brand equity [14].

The Marketing Science Institute [15] proposed five broad purposes for brand equity measures: (i) to guide marketing strategies and tactical decisions, (ii) to assess the extendibility of a brand, (iii) evaluate the effectiveness of marketing decisions, (iv) to track a brand's health in comparison to competitors over time, and (v) to assign a financial value to the brand in balance sheets and financial transactions. To this end, two approaches to measure brand equity have been proposed: the first, producing measures for the firm, focuses on the monetary or financial value of the brand in the marketplace and the second refers to a multidimensional concept that involves the value added to a product or service by consumers' associations and perceptions of a brand, normally conceptualized as consumer-based brand equity $[16,17,14]$. 


\subsection{Managing Brand Equity}

Effective brand management requires a long term view of marketing decisions. Since consumer's responses to marketing activity depends on what they know and remember about brand, short-term marketing actions, by changing brand knowledge necessarily increases or decreases the success of future marketing actions. Additionally, a longterm view results in proactive strategies designed to maintain and enhance customer-based brand equity overtime in the face of external changes in the marketing environment and internet changes in a firm's marketing goals and programmes [3]. There are three major ways of managing brand equity according to Kotler [3] Brand Reinforcement, Brand Revitalization, Brand Crisis.

\subsection{Concept of Brand Loyalty}

According to Egan [18] there are two approaches to define loyalty: behavioral and attitudinal loyalty. A definition of loyalty in attitudinal terms incorporates customer preferences and disposition towards brands to determine levels of loyalty. This approach is supported by Ball [19], who also distinguish between behavioral loyalty, which they define as repeated transactions that can be measured with observational techniques and attitudinal loyalty, which is defined as a positive affect towards the relationship prolongation, and the desire to continue to remain in the relationship. From the above, loyalty can be defined as a demonstrable and positive state of unselfish commitment and trust towards a specific service provider as a result of the evident and consistent satisfactory service levels it has provided to its customers, and can lead to repeat purchases or a lasting relationship. It also includes actions like positive word-of-mouth references and influencing their friends to support the same service provider.

Kincaid [20] defines customer loyalty "as a consumer behavior, built on positive experience and value, which leads to buying products, even when that may not appear to be the most rational decision". Furthermore, the concept was later divided in to behavioristic and non-behavioristic dimensions where the latter is more focused on the underlying causes of customer loyalty and attitudes of consumers. So, in the investigation of customer loyalty, it is valid to explore two fields: the behavior of consumers and their intentions [21].

\subsection{Measuring Brand Loyalty}

The overwhelming evidence today points to the power of triangulation - evidence of emotional loyalty coupled with one or more elements of functional, transactional, or contractual loyalty. Emotional loyalty overcomes problems, sustains the brand relationship, and drives a desire to repurchase. When paired with a strong rationale of a functional, contractual, or transactional nature, the combination works to erect barriers to competition and decrease price elasticity.

We know that the drivers of loyalty are complex, and may be based on different but equally important factors like experiences, beliefs, preferences, or fit with one's self-image. But if we are investing in improving our products, services, or processes, we need to link those investments to specific economic value creation. And because after-the-fact measurement approaches may come far too late to eliminate bad investments or course-correct those with minor flaws, we need methods for forecasting the creation of economic value based on changes we see early in the market response cycle. Some marketers measure loyalty by engagement. They monitor the correlations between customers' actual purchase behaviors and the use of the brand Web site, interactions with customer service channels, responses to price increases or discounts, etc.

Engagement actions, taken by the customer between purchase events, are generally good leading indicators of the customers' likeliness to repurchase or purchase complementary products or services. So the measure of true loyalty doesn't rely on any single indicator but rather several, all pointing in a common direction. Each kind of loyalty contractual, transactional, emotional, and functional is open to its own set of metrics [22].

\subsection{Concept of Perceived Product Quality}

There are various academics definition of the concept of perceived product quality. Johnson [23] describe perceived quality as the result of product performance which in turn can be labeled as the degree of customization and freedom from defects, or how reliably the product meets customer requirements. Perceived quality differs from objective quality, perceived product quality is a global assessment characterized by a high abstraction level and refers to a specific consumption setting. Objective quality refers to the actual technical excellence of the product that can be verified and measured [24].

Parasuraman [25] mentioned on the necessity of distinguishing product quality from service quality as the aspects which they are assessed differ. Consumers use product specific intrinsic cues to evaluate product quality. Intrinsic cues like flavor or color etc. are an inseparable and highly integral part of the product. Simultaneously, consumers also trust the relevant extrinsic product cues such a price, brand name and store name as indicators of product quality. Both theoretical and empirical arguments for the order of occurrence between quality and satisfaction have been put forward [34], and most marketing research accept a theoretical framework in which quality performance leads to satisfaction [26], which in turn influences purchasing behavior. So, the satisfaction is followed by quality performance has also been confirmed empirically, especially when quality is framed as a specific belief evolution and satisfaction as a more general evaluative construct. The "perceived quality" approach explains product quality from "the viewpoint of the consumer, making quality a subjective assessment dependent on perceptions, needs and goals of individuals" [23].

However, contrary to objective quality, perceived quality includes consumer's judgment about the superiority or 
excellence of a product. The objective or actual quality would have little or no impact unless the consumers perceive that the quality of products they are interested in meets their requirements. It can be viewed as the difference between overall quality and unobserved quality.

\subsection{Concept of Brand Awareness}

Aaker [16] defines awareness as 'the customers' ability to recall and recognize the brand as reflected by their ability to identify the brand under different conditions and to link the brand name, logo, symbol, and so forth to certain associations in memory". Brand awareness is the ability of consumers to recognize or remember a brand, and also link the brand and the product class, but the link does not have to be strong. Brand awareness is the probability that, consumers are well familiar with the availability and accessibility of a company's product and service.

Brand awareness means the ability of a consumer to recognize and recall a brand in different situations ${ }^{16}$. Brand awareness consists of brand recall and brand recognition. Brand recall means when consumers see a product category, they can recall a brand name exactly, and brand recognition means consumers ability to identify a brand when there is a brand cue. That is, consumers can tell a brand correctly if they ever saw or heard it. Aaker [16] identifies other higher levels of awareness besides recognition and recall. He includes top-of-mind, brand dominance, brand knowledge and brand opinion. Brand knowledge is the full set of brand associations linked to the brand [27].

Keller [17] indicate that brand awareness can be distinguished from depth and width. Depth means how to make consumers to recall or identify brand easily, and width is when the consumers want to purchase a product and the brand name is what come to their minds at once. If a product owns brand depth and brand width at the same time, consumers will think of a specific brand when they want to buy a product. That is, the product has higher brand awareness. Aaker [16] conceptualizes that brand awareness must precede brand associations. That is where a consumer must first be aware of the brand in order to develop a set of associations [14].

Brand awareness plays an important role on purchase intention because consumers tend to buy a familiar and well known product than an unfamiliar and unknown product [17]. Brand awareness can help consumers to recognize a brand from a product category and make purchase decision [14]. Brand awareness has a great influence on selections and can be a prior consideration base in a product category [17]. Brand awareness also acts as a critical factor in the consumer purchase intention, and certain brands will accumulate in consumers' mind to influence consumer purchase decision. A product with a high level of brand awareness will receive higher consumer preferences because it has higher market share and quality.

\subsection{Theoretical Framework}

Aaker's Brand Equity model
Capitalizing on the value of brand name, Aaker [8] described brand equity as an intangible value that accrues to a company as a result of its successful efforts to establish a strong brand. He theorized that the value of a company's brand equity can be calculated by comparing the expected future revenue from the branded product with the expected future revenue from an equivalent non-branded product. According to Aaker [16], this calculation is best on approximation. Thus, brand equity permits companies to charge premium prices for products and services, contributing to increased profit margins.

In his Brand Equity model, Aaker [16] identifies five brand equity components: (i) brand loyalty, (ii) brand awareness, (iii) perceived quality, (iv) brand associations and (v) other proprietary assets. A brand has positive customerbased brand equity when consumers react more favorably to a product and the way it is marketed when the brand is identified than when it is not. The concept provides a unique perspective on what brand equity is and how it should best be built, measured and managed.

The basic premise of the model is that the power of a brand lies in what customers have learned, felt, seen, and heard about the brand over time. In other words, the power of a brand resides in the minds of customers. These include enhancing brand awareness, perceived quality, brand association, brand loyalty and other proprietary assets. This study employ Customer-based brand equity model by Aaker [16] to underpin this study. Since this model has been proven to be reliable in previous studies, it is adopted in this study as well to determine the impact of the independent variable (Brand equity) on the dependent variable (Performance of distributors in Flour Mills of Nigeria PLC). Although it has yielded positive results in other industry previously, however it is important to see the outcome in a Fast-Moving Consumer Goods industry like Flour Mills of Nigeria PLC.

\section{Methodology}

This study apply survey method which is nonexperimental design, where the researcher does not have control over the independent variable (Brand Equity) affecting the dependent variable (Performance of distributors in Flour Mills of Nigeria PLC). The researcher can only control the measurement of the study but do not interfere with the research setting [28]. Thus, the study gathered information about the respondent's perception and understanding of those brand equity attributes or characteristics that affect Performance of distributors in Flour Mills of Nigeria PLC.

The population for this study are the distributors of Flour Mills of Nigeria PLC product in North Central Zone of Nigeria consisting of six state and the federal capital territory (Niger, Kwara, Nasarawa, Plateau, Benue, Kogi state and Abuja). This is a finite population made up of 231 distributors. Probability sampling technique was used. The probability sampling technique have a guarantee of equal and independent representation of data being chosen. 
The study applied Yamane's [29] formula in determining sample size of the population as follow;

Equation 1

$$
\begin{gathered}
\text { Require Sample Size }=\frac{\mathrm{N}}{1+\mathrm{N}(\mathrm{e}) 2} \\
\mathrm{~N}=\text { Total population chosen }=231 \\
\mathrm{e}=\text { Margin of error, }=0.05
\end{gathered}
$$

$$
\text { Required sample size }=\frac{231}{1+231(0.05) 2}
$$

The required sample size is 146. However, this was increased to 190 by adding $30 \%$. According to Israel [30], $10 \%$ to $30 \%$ could be added as attrition to make up for nonresponse. Thus, $30 \%$ of $146=44+146=189.8=190$

The data were collected using self-administered questionnaire. Face validity ware conducted to ensure proper adaptation of the questionnaire before a full-scale study. The adapted questionnaire from Atif \&, Malik [31], Bijuna \&, Sequeira [32] and Sudormo and Ulmi [33] measured how the research independent variables (Brand equity), significantly affect the dependent variable (Performance of distributors in Flour Mills of Nigeria PLC) The copies of the questionnaires were designed in a way that respondents were asked to indicate to what extent they agreed with a set of statements. A pilot study has been conducted, and the items were rated on a Likert scale. The constructs of the independent variable and dependent variable were validated through factor analysis during the pilot study. Since all the Cronbach's Alpha values of the constructs were above 0.70 the measuring items of each construct were deemed reliable.

Summary of the test of variables

Table 1. Case Processing Summary

\begin{tabular}{llll}
\hline & $\mathbf{N}$ & $\mathbf{\%}$ \\
\hline \multirow{3}{*}{ Cases } & Valid & 30 & 100.0 \\
& Excluded $^{\mathrm{a}}$ & 0 & .0 \\
& Total & 30 & 100.0 \\
\hline
\end{tabular}

a. Listwise deletion based on all variables in the procedure.
Table 2. Reliability Statistics.

\begin{tabular}{lll}
\hline Cronbach's Alpha & $\begin{array}{l}\text { Cronbach's Alpha Based on } \\
\text { Standardized Items }\end{array}$ & N of Items \\
\hline .849 & .861 & 21 \\
\hline
\end{tabular}

The cut-off point for measuring reliability in the brand equity study must be at least 0.70 or greater as suggested by Bijuna \&, Sequeira [32].

This study uses a frequency of responses of the modified 4-point Likert scale options of strongly agree, agree, disagree and strongly disagree carrying points of 4, 3, 2 and 1 respectively with their corresponding mean scores. A cumulative score in each of the sections is computed and compared with a standard deviation mean of 2.500 which was computed based on the 4-Likerts scale options, computed, thus: $(4+3+2+1) / 4=2.5$. A cumulative mean above the standard mean indicates positive response or agreement on the question, and if otherwise a negative response or disagreement. The researcher uses the p-value of 0.05 as level of significant for testing all the hypotheses as justified by Ringim [28] who argued that respondents have behavior of either survey optimizing or satisfying. Thus, including neutral point could lead to decrease in measurement quality.

Equation 2

The model for the study is specified thus:

$$
Y=\alpha+\beta_{1} \alpha_{1}+\beta_{2} \alpha_{2}+\beta_{3} \alpha_{3}+\beta_{4} \alpha_{4}
$$

Where, $\beta=$ Coefficient of the Dependent varriables (performance.)

$\alpha=$ Independent Variable (Perceive product quality, Brand awareness, Brand Association, Brand loyalty)

$\mathrm{Y}=$ Performance of distributors, $\alpha 1=$ perceive product quality, $\alpha 2=$ Brand awareness, $\alpha 3=$ Brand Association, $\alpha 4=$ Brand Loyalty.

\section{Data Analysis and Findings}

$\mathrm{H} 0^{1}$ : There is no significant effect of perceived product quality on the performance of distributors in Flour Mills of

\begin{tabular}{|c|c|c|c|c|c|c|c|c|c|}
\hline \multirow{2}{*}{ Model } & \multirow{2}{*}{$\mathbf{R}$} & \multirow{2}{*}{ R Square } & \multirow{2}{*}{$\begin{array}{l}\text { Adjusted R } \\
\text { Square }\end{array}$} & \multirow{2}{*}{$\begin{array}{l}\text { Std. Error of the } \\
\text { Estimate }\end{array}$} & \multicolumn{5}{|l|}{ Change Statistics } \\
\hline & & & & & R Square Change & F Change & df1 & df2 & Sig. F Change \\
\hline 1 & $.697^{\mathrm{a}}$ & .485 & .482 & 1.58947 & .485 & 168.819 & 1 & 179 & .000 \\
\hline
\end{tabular}
Nigeria PLC

Regression on the effect of perceived product quality on the performance of distributors in Flour Mills of Nigeria PLC

Table 3. Model Summary.

a. Predictors: (Constant), perceived product quality

Table 4. Coefficients ${ }^{a}$.

\begin{tabular}{llllll}
\hline \multirow{2}{*}{ Model } & & \multicolumn{2}{l}{ Unstandardized Coefficients } & \multicolumn{2}{l}{ Standardized Coefficients } \\
\cline { 3 - 5 } & & B & Std. Error & Beta & \\
\hline \multirow{2}{*}{1} & (Constant) & 23.745 & 1.106 & & 21.461 \\
& Perceived product quality & .519 & .000 & .697 & 12.993 \\
\hline
\end{tabular}

a. Dependent Variable: PERFORMANCE OF DISTRIBUTORS 
Results of Multiple Regression statistics in table 3 above revealed that there is significant effect of product Quality on performance of distributors in Flour Mills of Nigeria PLC. Reasons being that the computed $\mathrm{P}$ value of 0.000 is lower than the 0.05 alpha level of significance and computed $F$ value of 168.819 is higher than the $3.000 \mathrm{~F}$ critical. it was also revealed that the computed $R$ value of $0.697, R^{2}$ of 0.485 and Adjusted $\mathrm{R}^{2}$ of 0.482 is each higher than the 0.4000 standard $\mathrm{R}$ implying that the effect of product quality on performance of distributors in Flour Mills of Nigeria PLC is very strong

The coefficient statistics in table 4 also showed that the effect between the dependent variable and the independent variable is very high with a value of 0.697 The coefficient table showed that $\mathrm{Y}=\mathrm{a}+\mathrm{b} * \mathrm{X}$. Where $\mathrm{Y}=$ performance of distributors in Flour Mills of Nigeria PLC, $a=23.745, b=$ $1.106 \mathrm{X}=0.519$. Therefore, the null hypothesis which state that product quality has no significant effect on the performance of distributors in Flour Mills of Nigeria PLC, is hereby rejected.

$\mathrm{H}^{2}$ : There is no significant effect of Brand awareness on performance of distributors in Flour Mills of Nigeria PLC.

Linear Regression on effect of Brand awareness on the performance of distributors in Flour Mills of Nigeria PLC.

Table 5. Model Summary.

\begin{tabular}{|c|c|c|c|c|c|c|c|c|c|}
\hline \multirow{2}{*}{ Model } & \multirow{2}{*}{$\mathbf{R}$} & \multirow{2}{*}{ R Square } & \multirow{2}{*}{$\begin{array}{l}\text { Adjusted R } \\
\text { Square }\end{array}$} & \multirow{2}{*}{$\begin{array}{l}\text { Std. Error of the } \\
\text { Estimate }\end{array}$} & \multicolumn{5}{|l|}{ Change Statistics } \\
\hline & & & & & R Square Change & F Change & df1 & df2 & Sig. F Change \\
\hline 1 & $.790^{\mathrm{a}}$ & .624 & .622 & 1.35921 & .624 & 296.645 & 1 & 179 & .000 \\
\hline
\end{tabular}

a. Dependent Variable: PERFORMANCE OF DISTRIBUTORS

a. Predictors: (Constant), Awareness

Table 6. Coefficients ${ }^{a}$.

\begin{tabular}{llllll}
\hline Model & & Unstandardized Coefficients & Standardized Coefficients & T \\
\cline { 3 - 5 } & & B & Std. Error & Beta & \\
\hline 1 & (Constant) & 21.261 & .979 & & 21.710 \\
& Awareness & .647 & .038 & .790 & .000 \\
\hline
\end{tabular}

a. Dependent Variable: PERFORMANCE OF DISTRIBUTORS

Results of Multiple Regression statistics in table 5 above revealed that there is significant effect of Brand awareness on performance of distributors in Flour Mills of Nigeria PLC. Reasons being that the computed $\mathrm{P}$ value of 0.001 is lower than the 0.05 alpha level of significance and computed $F$ value of 296.645 is higher than the $3.000 \mathrm{~F}$ critical. it was also revealed that the computed $\mathrm{R}$ value of $0.790, \mathrm{R}$ square of 0.624 and Adjusted R square of 0.622 is each higher than the 0.4000 standard $\mathrm{R}$ implying that the effect of Brand awareness on performance of distributors is very strong.

The Coefficient statistics in table 6 showed that both the
Tolerance values and the VIF value are high with value of 0.790 which further shows that brand awareness has high effect on the performance of distributors in Flour Mills of Nigeria PLC. Therefore, the null hypothesis which state that Brand awareness has no significant effect on the performance of distributors in Flour Mills of Nigeria PLC, is hereby rejected.

$\mathrm{H}^{3}$ : There is no significant effect of brand association on performance of distributors in Flour Mills of Nigeria PLC.

Linear regression on the effect of Brand association on performance of distributors in Flour Mills of Nigeria PLC.

Table 7. Model Summary.

\begin{tabular}{llllllllll}
\hline \multirow{2}{*}{ Model } & \multirow{2}{*}{$\mathbf{R}$} & \multirow{2}{*}{ R Square } & \multirow{2}{*}{ Adjusted R Square } & $\begin{array}{l}\text { Std. Error of the } \\
\text { Estimate }\end{array}$ & \multicolumn{2}{l}{ Change Statistics } \\
\cline { 5 - 9 } & & & R Square Change & F Change & df1 & df2 & Sig. F Change \\
\hline 1 & $.649^{\mathrm{a}}$ & .422 & .418 & 1.68498 & .422 & 130.502 & 1 & 179 & .000 \\
\hline
\end{tabular}

a. Predictors: (Constant), BrandAssociation

Table 8. Coefficients ${ }^{a}$.

\begin{tabular}{llllll}
\hline \multirow{2}{*}{ Model } & & \multicolumn{2}{l}{ Unstandardized Coefficients } & \multicolumn{2}{l}{ Standardized Coefficients } \\
\cline { 3 - 5 } & & B & Std. Error & Beta & \multirow{2}{*}{ Sig. } \\
\hline \multirow{2}{*}{1} & (Constant) & 27.591 & .923 & & 29.891 \\
& Brand Association & .436 & .038 & .649 & 11.424 \\
\hline
\end{tabular}

a. Dependent Variable: PERFORMANCE

Results of Multiple Regression statistics in table 7 above revealed that Brand association has significant effect on performance of distributors in Flour Mills of Nigeria PLC. Reasons being that the computed $\mathrm{P}$ value of 0.001 is lower than the 0.05 alpha level of significance and computed $F$ value of 130.502 is higher than the $3.000 \mathrm{~F}$ critical. it was also revealed that the computed $\mathrm{R}$ value of 0.649 , $\mathrm{R}$ square of 0.422 and Adjusted R square of 0.418 is each higher than the 0.4000 standard $\mathrm{R}$ implying that the effect of Brand association on performance of distributors in Flour Mills of 
Nigeria PLC is very strong.

The Coefficients statistics in table 8 showed that both the Tolerance values and the VIF value are high which further shows that brand association has high effect on the performance of distributors in Flour Mills of Nigeria PLC. Consequently, the null hypothesis which state that brand association has no significant effect on profitability of Flour
Mills of Nigeria PLC, is hereby rejected.

$\mathrm{H} 0^{4}$ : There is no significant effect of Brand loyalty on performance of distributors in flour mills of Nigeria

Linear regression statistics on the effect of Brand loyalty on the performance of distributors in Flour Mills of Nigeria PLC.

Table 9. Model Summary.

\begin{tabular}{|c|c|c|c|c|c|c|c|c|c|}
\hline \multirow{2}{*}{ Model } & \multirow{2}{*}{$\mathbf{R}$} & \multirow{2}{*}{ R Square } & \multirow{2}{*}{$\begin{array}{l}\text { Adjusted } \\
\text { R Square }\end{array}$} & \multirow{2}{*}{$\begin{array}{l}\text { Std. Error of the } \\
\text { Estimate }\end{array}$} & \multicolumn{5}{|l|}{ Change Statistics } \\
\hline & & & & & R Square Change & F Change & df1 & df2 & Sig. F Change \\
\hline 1 & $.705^{\mathrm{a}}$ & .496 & .494 & 1.57242 & .496 & 176.401 & 1 & 179 & .000 \\
\hline
\end{tabular}

a. Predictors: (Constant), BrandLoyalty

Table 10. Coefficients ${ }^{a}$.

\begin{tabular}{|c|c|c|c|c|c|c|}
\hline \multirow{2}{*}{ Model } & & \multicolumn{2}{|c|}{ Unstandardized Coefficients } & \multirow{2}{*}{$\begin{array}{l}\text { Standardized Coefficients } \\
\text { Beta }\end{array}$} & \multirow{2}{*}{$\mathbf{T}$} & \multirow{2}{*}{ Sig. } \\
\hline & & B & Std. Error & & & \\
\hline 1 & (Constant) & 25.355 & .962 & & 26.354 & .000 \\
\hline 1 & BrandLoyalty & .538 & .041 & .705 & 13.282 & .000 \\
\hline
\end{tabular}

a. Dependent Variable: PERFORMANCE OF DISTRIBUTORS

Results of Multiple Regression statistics in table 9 above revealed that Brand loyalty has significant effect on performance of distributors in Flour Mills of Nigeria PLC.

Reasons being that the computed $\mathrm{P}$ value of 0.020 is lower than the 0.05 alpha level of significance and computed $\mathrm{F}$ value of 176.401 is higher than the $3.000 \mathrm{~F}$ critical. it was also revealed that the computed $\mathrm{R}$ value of 0.649 , $\mathrm{R}$ square of 0.422 and Adjusted R square of 0.418 is each higher than the 0.4000 standard $\mathrm{R}$ implying that the effect of Brand loyalty on performance of distributors in Flour Mills of Nigeria PLC is very strong.

The coefficient statistic in table 10 showed that the data model can be used to forecast further values of performance of distributors in Flour Mills of Nigeria PLC if the level of Brand loyalty is measured, using the formula $\mathrm{Y}=\mathrm{a}+\mathrm{b} * \mathrm{X}$ : where $\mathrm{Y}=$ performance of distributors, $\mathrm{a}=25.355, \mathrm{~b}=0.962$ and $\mathrm{X}=$ brand loyalty

Therefore, the null hypothesis which state that Brand loyalty has no significant effect on the performance of distributors in Flour Mills of Nigeria PLC, is hereby rejected.

\section{Discussion of the Findings.}

This study revealed that there is significant positive effect of Perceived Product Quality on performance of distributors in Flour Mills of Nigeria PLC. Flour Mills of Nigeria PLC need to ensure that customers are satisfy, among others, with the quality of their products, and they logically have to continuously improve their quality (based on the requirements of customers). It has established that product quality is an essential ingredient in retaining customers as a result of the satisfaction they derive from the quality of the product (especially product quality attribute like durability, reliability, performance, esthetic etc. are consistence) which increase customer patronage and performance of distributors in Flour Mills of Nigeria PLC.
Secondly the finding of the study shows that there is significant positive effect of Brand awareness on the performance of distributors in Flour Mills of Nigeria PLC. This finding is of great value for the marketing department, especially the Brand managers who have to maintain and increase Customer awareness through the creation of advertisement, radio jingle etc. This means that if the distributor is well aware about flour mills of Nigeria brand and have all the required knowledge about it, it will lead to higher level of satisfaction about that brand and increase the performance of distributors in Flour Mills of Nigeria PLC.

Thirdly the study found that there is significant positive effect of Brand association on the performance of distributors in Flour Mills of Nigeria PLC. This is because associations are formed by customers on the basis of quality perceptions, how they interact with employees and the organization, the effectiveness of advertisements of the brand, points of price at which the brand is sold, product categories that the brand is in, how product are display in retail stores, publicity in various media, offerings of competitors, celebrity associations and from what others tell them about the brand.

Lastly, the study revealed that there is significant positive effect of brand loyalty on the performance of distributors in Flour Mills of Nigeria PLC. This implies that organizational performance in terms of its distributors is positively and significantly tied to the level of brand loyalty its distributors have developed for its brands. Consequently, performance of distributors is a functions of brand loyalty to its products.

\section{Conclusion}

Base on the findings, this study draws its conclusion on the fact that the level of performance of distributors in Flour Mills of Nigeria PLC is greatly influenced by factors such as Product's brand acceptance, and that the product perceive quality influences increase to market share of the company 
which as a result increase patronage and performance of distributors

\section{Recommendations}

These recommendations are put forward to further improve the level of performance of distributors in Flour Mills Nigeria plc:

i. It is recommended that products should carry the requisite quality measures such as the recipe and basic instruction on how to use the product for maximum satisfaction in other to create confidence in the mind of distributors, all this should be translated into the three major Nigeria languages rather than using English language only, as this will further increase patronage and performance of distributors in Flour Mills of Nigeria PLC.

ii. The company should increase the intensity of creating awareness of the activities of Flour Mills of Nigeria PLC on radio, television and development of internet blogs and sponsoring of social event, this will further create more awareness and improve the performance of distributors in Flour Mills Nigeria Plc

iii. The customers continuous positive perception should be sustained through incentives such as promotions and giving out gifts such as trucks, cash, aprons, and so on to dedicated customers, maintaining consistence quality of the product and ensure delivery at the right time. This will make customers to have confidence whenever the need arises to buy Flour Mills of Nigeria PLC brand, and will increase positive association and performance of distributors.

iv. Customers satisfaction at all times should be guaranteed through measures such as quantity and quality increase, effective distribution channels and affordability, effective inter personal relationship between the organizational staff and customers. This will ensure continuous patronage leading to mouth to mouth communication with other prospective users thereby increase performance of distributors in Flour Mills of Nigeria PLC.

\section{References}

[1] Ali, I. M (2014) Corporate Brand Equity and Firm Performance in The Pharmaceutical Industry in Kenya' MSc Dissertation, School of Business, University of Nairobi, Kenya.

[2] Aaker, D. A., V. Kumar, R. P. Leone, dan George S. Day. (2013) Marketing Research. International Student Version. 11th Edition. John Wiley \& Son, Singapore.

[3] Kotler, P and Keller K. L. (2006) Marketing Management, 12th Ed. New Jersey, Prentice Hall.

[4] Orji M. G, Akhimien E, Solomon A. B, Patience U. I (2016). "Assessing Brand Equity and Customer Satisfaction as Tools for Profit Optimization in Nigeria," Science Journal of Business and Management. Vol 4, no.5, pp 165-171.

[5] Jubrin, F. (2014). "Effect of Brand Equity and Customer Satisfaction on the Performance of Nigerian Bottling
Company Limited. Unpublished MBA thesis; Department of business Administration, Ahmadu Bello University Zaria, Nigeria

[6] Michel L. J,. (1995), Perfomance Measurement And Performance Management, International Journal Of Production, Vol. 41, No. 1-3.

[7] Wholey J. S., (1996), Formative And Summative Evaluation: Related Issues In Performance Measurement, American Journal Of Evaluation, Vol. 17, No. 2.

[8] Kane, J S., (1996) The conceptualisation and representation of total performance effectiveness, Human Resource Management Review, 12 (8) 123-145

[9] Brumback, G. B., (2003). Blending The "We/Me" In Performance Management. International Journal Of Team Performance Management, 7 (8), 167-73.

[10] Keller, K. L. (2013). Strategic Brand Management: Building, Measuring, and Managing Brand Equity (Global Edition ed.). Essex CM20 2JE: Pearson.

[11] Omar, O. E., (1999). Retail Marketing. Harlow: Pearson Education, Inc. publishing, Prentice Hall.

[12] Rosenbloom, B., (2004). Multichannel Marketing: Mindset And Program Development. Business Horizons, 50 (7) 385394.

[13] Baldauf, A., Cravens K. S. And Binder G., (2003). "Performance Consequences Of Brand Equity Management: Evidence From Organizations In The Value Chain," Journal Of Product \& Brand Management, 12 (4): 220-236.

[14] Washburn, J.

[15] H. and Plank, R. E. (2002), "Measuring Brand Equity: an Evaluation of a Consumer- Based Brand Equity Scale," Journal of Marketing Theory and Practice. Vol.10, no.1, pp 46-61.

[16] Marketing Science Institute. (1999). Current research priorities. Retrieved http://www.msi.org/about/1999researchpriorities

[17] Aaker, D. A. (1996). Measuring Brand Equity across Products and Markets. California Management Review, Vol. 38, No. 3, pp. $102-120$

[18] Keller, A. (2004). Conceptual insights and research priorities. Journal of Retailing, pp 331-342.

[19] Egan John (2008). Relationship Marketing: Exploring Relational Strategies in Marketing. Financial Times Prentice Hall.

[20] Ball, D. and Coelho P. S. and Mache's, A. (2004). The role of communication and trust in explaining customer loyalty: An extension to the ECSI model. European Journal of Marketing, $38(9 / 10), 1272-1293$.

[21] Kincaid, J. (2003). Customer Relationship Management: getting it right. London: Prentice Hall Professional.

[22] Schweizer, B. (2008). An Examination of Factors Leading to Abating Customer Loyalty Towards Magazine Subscriptions, Berlin: GRIN Verlag.

[23] Clow, M. (2010). Integrated Marketing Communications. Pearson Education, Inc. publishing, Prentice Hall. 
[24] Johnson, M. D. \& Ettlie, J. E. (2004), "Technology, customization, and reliability", Journal of Quality Management, Vol 6. No (2): pp 193-210.

[25] Zeithaml, Valarie A. (1988). "Consumer Perceptions of Price, Quality and Value: A Means- End Model and Synthesis of Evidence," Journal of Marketing Research. Vol. 52, no. 3, pp $2-22$.

[26] Parasuraman, A., \& Grewal, D. (2000). The impact of technology on the quality-value-loyalty chain: A research agenda. Journal of the Academy of Marketing Science, 28 (1), $168-174$.

[27] Dabholkar, P. A., Shepherd, C. D. \& Thorpe, D. I. (2000), “A comprehensive framework for service quality: An investigation of critical conceptual and measurement issues through a longitudinal study", Journal of Retailing, Vol 76. No (2). Pp 139-173.

[28] Keller, Kevin Lane (2003). Strategic Brand Management: Building, Measuring, and Managing Brand Equity, Second Edition, Upper Saddle River, NY: Prentice Hall. U. K.

[29] Ringim, K. J. (2012) Perception, Awareness and Understanding of Muslim Account holder in Conventional bank toward Islamic Banking Products. Being Msc Thesis submitted to Kolej University Insaniah Malaysia.
[30] Yamane, (1967). Statistics: An Introductory Analysis, 2nd Edition, New York: Harper and Row.

[31] Isreal. G. (1992) "Sampling techniques" Retrieved from http.lledis.ifas edu/pdfiles/pd/pd006.pdf

[32] Atif. B. \& Malik. F. M (2014) "Impact of brand equity \& brand awareness on customer's satisfaction' International journal of modern management $\&$ foresight, vole 1 , no.10, pp $112-132$.

[33] Bijuna, C. M and Sequeira, A. H. (2016).“The impact of customer-based brand equity on the operational performance of FMCG companies in India'IIMB Management Review, vol 28, PP13-19.

[34] Sudarmo S, Sucherly. E, Nury. E, Umi. K (2017) Brand equity and competitive advantage based market strategy and Marketing mix strategy to improve marketing performance In the bottled water business' South East Asia Journal of Contemporary Business, Economics and Law, Vol. 12/2 J

[35] Cronin, J. J., Brady, M. K., \& Hult, G. T. M. (2000). Assessing the effects of quality, value, and customer satisfaction on consumer behavioral intentions in service environments. Journal of Retailing, 76 (2), 193-218. 